ÊESTI NSV TÉADUSTE AKADEEMIA TOIMETISED. 30. KOIDE GEOLOOGIA, 1981, NR. 1

ИЗВЕСТИЯ АКАДЕМИИ НАУК ЭСТОНСКОЙ ССР. ТОМ 30 ГЕОЛОГИЯ. 1981, № 1

\title{
О ПАЛЕОТЕКТОНИЧЕСКИХ ИССЛЕДОВАНИЯХ В ПРИБАЛТИКЕ И БЕЛОРУССИИ
}

Развитие исследований истории формирования структуры рифейско-фанерозойского платформенного чехла запада Русской плиты базируется на относительно полной изученности этого региона глубокими скважинами. Достигнутые результаты и опыт палеотектонических исследований позволяют геологам западного региона СССР участвовать в проекте № 86 МПГК «Юго-западный край Восточно-Европейской платформы». Прибалтика и Белоруссия расположены на северо-восточной части территории, охватываемой этим проектом, во внутренней части платформы и характеризуются относительно стабильным тектоническим режимом в течение рифея-фанерозоя.

Результаты палеотектонических исследований региона были. доложены и обсуждены на VIII совещании, организованном комиссией по тектонике Белоруссии и Прибалтики Тектонического комитета СССР в Таллине в ноябре 1980 г. (Палеотектоника..., 1980). На этом совещании были даны, в частности, описание тектоники территории Белоруссии в рифее-палеозое (Г. В. Зиновенко, И. В. Климович, 3. А. Горелик и др.), тектоническая интерпретация фациального профиля силурийского Балтийского бассейна (Р. Э. Эйнасто, В. А. Пуура), характеристика палеогеоморфологических условий средней Прибалтики на рубеже каледонского и герцинского тектонических циклов (И. А. Поливко) и особенностей тектонического режима областей сноса раннесреднедевонских бассейнов северо-запада Евразии (В. М. Куршс) и др. В своем докладе (совместный с Р. Е. Айзбергом и П. И. Сувейздисом) и в ходе обсуждений Р. Г. Гарецкий остановился на основных методах палеотектонических реконструкций платформенных территорий и результатах их применения на конкретных примерах исследований запада Русской плиты. Он выделил 2 возможных типа палеотектонических карт: 1) стадийно-временные (поинтервальные) и 2) карты тектоннческих (геохронологических) рубежей, а также 2 вида стадийно-временных карт, характеризующие): а) талассократические (седиментацнонные) и б) геократические (денудационные, перерывные) эпохи.

При подведении итогов работы VIII совещания было учтено, что вопросы палеотектоники региона обсуждались также на IV-VII совещаниях в 1975-1978 гг. (Проблемы ..., 1979; Региональная..., 1977; Тектоника..., 1978; Локальные ..., 1978). Настоящее совещание рекомендовало в дальнейшем уделять больше внимания 1) изучению глубинного строения земной коры (в частности, проложению профилей глубинного сейсмического зондирования) и широким региональным обобщениям и 2) формационным, фациальным и паләогеоморфологическим исследованиям как основе палеотектонического анализа и поисков полезных ископаемых.

На фоне общих проблем Белорусско-Прибалтийского региона выделяется несколько задач, решения которых необходимо и возможно добиться на основе матерналов по Эстонии и сопредельным регионам: 1) морфологическая характернстика осадочных тел и интерпретация геоморфологии и тектоники дна древних бассейнов на основе формационных и фациальных исследований, 2) характеристика палеотектонических и палеогеографических особенностей формирования бассейнов полезных ископаемых (в частности, горючих сланцев, фосфоритов), 3) выяснение возможных связей между надрегиональными (глобальными) тектоническими процессами и формированием древних бассейнов осадконакопления, региональных и локальных тектонических структур платформы. 


\section{ЛИТЕ РА Т У РА}

Локальные структуры Прибалтики и Белоруссии. (Тез. VII совещания). Вильнюс, 1979.

Палеотектоника Прибалтики и Белоруссии. (Тез. VIII совещания). Таллин, 1980.

Проблемы унаследованности тектонических структур в Прибалтике и Белоруссии. (Мат-лы IV совещания). Таллин, 1979.

Региональная тектоника Белоруссии и Прибалтики (Мат. V совещания). Минск, 1977. Тектоника и полезные ископаемые Белоруссии и Прибалтики (Мат-лы VI совещания). Калининград, 1978.
Институт геологии
Академии наук Эстонской ССР
Поступила в редакцию 26/XII 1980

УДК $551.732: 552.56: 549.742 .114(438+474)$

Диагенетический сидерит в отложениях нижнего кембрия Польши и стратиграфическое значение этой минерализации. Арень Б., Лендзион К., Пиррус Э. Изв. АН ЭстССР. Геология, 1981, т. 30, № 1, с. $1-6$ (рез. эст., англ.)

Описаны сидеритопроявления в скв. Мельник (Восточная Польша), Бартошице и Голдап (Северная Польша), которые располагаются на одном и том же стратиграфическом уровне с оолитовыми гетитовыми рудами центральной части Балтийской синеклизы. Эти находки свидетельствуют о распространенности железной минерализации данного типа на весьма обширной площади, что в свою очередь расширяет маркирующее значение этих минералопроявлений в стратиграфической практике.

Сидериты в разрезах Польши содержат значительный объем силикатного скелета вмещающих пород, а в составе карбонатного компонента кроме сидерита нередко - железистый доломит. Этим они несколько отличаются от сидеритовых образований, найденных в разрезах Латвии - в зоне выклинивания гетитовых оолитовых руд.

Высказывается предположение, что образование гетит-сидеритовой ассоциации осадочного рудопроявления обусловлено кратковременным, но регионально выраженным отклонением нормальноморского режима седиментации в раннекембрийском море в сторону некоторого опреснения вод бассейна. Рнс, 2. Табл. 1. Бнбл. 5 назв.

\section{УДК $543.8: 553.973(474.2)$}

Компонентный состав органического вещества сапропелей малых озер Эстонии и некоторые пути их использования. С а а р с Л., К а с к Ю. - Изв. АН ЭстССР. Геология, 1981 , т. 30, № 1, с. $7-11$ (рез. эст., англ.)

Определен групповой компонентный состав органической массы сапропелей некоторых малых озер Эстонии и сделаны выводы, что изученные сапропели отличаются пониженным содержанием водо- 